\title{
A detailed report on the measures taken in the Department of Conservative Dentistry and Periodontology in Munich at the beginning of the COVID-19 outbreak
}

\author{
Christian Diegritz ${ }^{1}$ (D) · Jürgen Manhart ${ }^{1} \cdot$ Katharina Bücher $^{1} \cdot$ Béatrice Grabein ${ }^{2} \cdot$ Günther Schuierer $^{2} \cdot$ Jan Kühnisch $^{1}$. \\ Karl-Heinz Kunzelmann ${ }^{1} \cdot$ Reinhard Hickel $^{1} \cdot$ Christina Fotiadou $^{1}$
}

Received: 21 April 2020 / Accepted: 26 June 2020 / Published online: 1 July 2020

(C) Springer-Verlag GmbH Germany, part of Springer Nature 2020

\begin{abstract}
Objectives The corona disease (COVID-19) is developing into one of the greatest challenges for healthcare professionals around the world. In this article, we report the detailed actions taken in the Department of Conservative Dentistry and Periodontology, University Hospital, Ludwig-Maximilians-University (LMU), Munich, Germany, during the early phase of the COVID-19 pandemic.

Material and methods After a joint on-site inspection of the dental clinic with the Department of Clinical Microbiology and Hospital Hygiene, existing clinical and hygiene protocols were adapted for COVID-19 patients.

Results A comprehensive summary of the preparation of the facilities as well as pre- treatment, treatment and posttreatment protocols are described and arising problems are being discussed.

Conclusions The importance of rigorous hygiene and treatment protocols as well as a sufficient supply of PPE for dental offices and hospitals is highlighted. The measures reported may be subject to change due to the dynamics of the pandemic.

Clinical relevance The modes of transmission of the severe acute respiratory syndrome coronavirus 2 (SARS-CoV-2) (e.g., droplets, aerosols, and fomites) can pose a risk for dental healthcare professionals and patients alike. The presented measures may guide dental faculties and dental practices during the early stage of the COVID-19 crisis.
\end{abstract}

Keywords COVID-19 $\cdot$ SARS-CoV-2 $\cdot$ Dentistry $\cdot$ Dental hygiene protocol $\cdot$ Dental treatment protocol

\section{Chronic of the COVID-19 outbreak}

In December 2019, the first cases of patients with pneumonia of unknown origin were described in Wuhan city, Hubei Province, China [1]. In January 7, 2020, a novel $\beta$-coronavirus was isolated and declared as the causative pathogen [2]. The virus was officially named "severe acute respiratory syndrome coronavirus 2" (SARS$\mathrm{CoV}-2$ ) and has since then spread rapidly around the globe [3]. On January 30, the World Health Organization declared the COVID-19 outbreak a public health emergency of international concern [4]. As

Christian Diegritz

diegritz@dent.med.uni-muenchen.de

1 Department of Conservative Dentistry and Periodontology, University Hospital, LMU, Munich, Germany

2 Department of Clinical Microbiology and Hospital Hygiene, University Hospital, LMU, Munich, Germany of April 12, 1,695,096 cases, in 213 countries, and 105.865 fatalities have been reported worldwide, with daily increasing numbers.

The first confirmed case of the coronavirus disease (COVID-19) in Germany was diagnosed on January 27 in Munich, Bavaria [5]. Although initially the spreading could be contained due to immediate contact tracing and strict isolation measures, new cases appeared all over Germany as of February 26 [6]. This development lead to a cascade of events that include the activation of the crisis task force (February 27) and the initiation of the Robert Koch Institute (RKI) pandemic plan followed by the gradual lock down of daycare centers, schools, and universities (March 14) and the declaration of a curfew and a contact ban (March 22) [6].

\section{SARS-CoV-2}

The SARS-CoV-2 is a novel $\beta$-coronavirus of the Coronaviridae family [2]. Coronaviruses are most 
common in vertebrates and show zoonotic characteristics. In the last 20 years, two other viruses of the same subfamily have been associated with epidemic outbreaks: the severe acute respiratory syndrome coronavirus (SARS-CoV) in Guangdong Province of China in 2002 and the Middle Eastern respiratory syndrome coronavirus (MERS-CoV) which lead to a severe respiratory outbreak in 2012. Interestingly, both SARS-CoV and SARS-CoV-2 use the same host receptor, namely, the human angiotensin-converting enzyme 2 (ACE2) [7-9]. Although genomic similarities between SARSCoV-2 and SARS-CoV of $79 \%$ and SARS-CoV-2 and the MERS-CoV of 50\% [10] have been described, the main difference between these viruses arises from the point of infectivity: The viral load of asymptomatic infected patients seems to be similar to the load of early symptomatic patients [11] indicating asymptomatic transmissibility of SARS-CoV-2 [12-14]. Additionally, SARS-CoV-2 infection probability has been calculated to be 1.9 times higher than SARS-CoV [15].

\section{Transmission mode}

The main mode of transmission of SARS CoV-2 is via droplets (coughing, gagging, sneezing) and direct contact which poses a risk to the mucosae (mouth and nose) and conjunctivae [16-18]. Up to this date, there is only limited evidence of airborne transmission of viable virus via aerosols (droplets < $5 \mu \mathrm{m})$ [19]. Van Doremalen and co-workers demonstrated, under experimentally induced aerosol in laboratory conditions, that SARS-CoV-2 remained viable in aerosols for at least $3 \mathrm{~h}$ and on surfaces for up to $72 \mathrm{~h}$. The longest viability was found on stainless steel (estimated medial half-life: $5.6 \mathrm{~h}$ ) and plastic surfaces (estimated medial half-life: $6.8 \mathrm{~h}$ ) [20]. Earlier studies on SARS and MERS-CoV virus suggest a surface survival of the viruses up to 9 days [21] which is higher than other respiratory viruses such as influenza [22]. Therefore, indirect transmission through self-inoculation via infected surfaces and objects is possible [22, 23].

Furthermore, SARS CoV-2-RNA was detected in stool raising the possibility of fecal-oral transmission [18, 24-26].

\section{COVID-19: Incubation time and symptoms}

A mean incubation time of 5 days with an incubation period of 2-14 days has been estimated [27, 28]. The virus can be detected 2 days prior to symptoms until approximately 8 days after onset of symptoms [28], but also longer detection times have been described $[29,30]$.

Commonly reported symptoms have been dry cough, fever, rhinitis, and pneumonia, whereas less typical symptoms seem to be muscle pain, sore throat, diarrhea, and headaches [31]. Recently, several reports described an olfactory loss of patients [28, 32]. Giacomelli and colleagues reported that $33.9 \%$ of the cohort suffered from anosmia or hyposmia [33].

\section{Implications for dental universities}

The high infectivity of SARS CoV-2 and the transmission modes of the virus through droplets, aerosol, direct contact, and surface contamination position the dental health professionals in a group of high exposure risk $[28,34,35]$. In order to avoid nosocomial infection in the dental hospital, the crisis task force of the University Hospital of the LMU has been given instructions to stop elective dental treatments and focus only on emergencies. Additionally, in accordance with the recommendations of social distancing, on-site training of students has ceased till further notice and efforts are made to establish and enlarge online teaching platforms.

Besides using already existing e-learning courses which are provided by platforms such as the "Virtual University of Bavaria" (VHB), further e-learning experiences have been introduced: Lectures were either presented live via a ZOOM meeting (Zoom Video Communications, USA) or prerecorded and uploaded on the Moodle platform of the clinic. All lectures were also provided in advance as a downloadable document.

In close collaboration with the Department of Clinical Microbiology and Hospital Hygiene, strict hygiene and patient management protocols have been developed and applied. Furthermore, educational hygiene and psychological support programs have been created in order to continuously support and strengthen the moral of the dental staff. In this article, we would like to present a detailed overview of the measures taken in the Department of Conservative Dentistry and Periodontology, University Hospital, LMU Munich, at the beginning of the COVID-19 pandemic. The measures described are subject to change as we learn more about the disease on a daily basis.

\section{Circulation of information, regulations, and training programs}

In times of healthcare crises, an adequate and timely distribution of information is essential. To counteract fears and uncertainties, daily e-mail messages of the hospital command center, updating the staff on the current COVID-19 situation, including number of patients with COVID-19 and occupancy rate of ICUs (intensive care units), have been established. Furthermore, educating platforms and training courses have been introduced in order to lessen the psychological burden of the medical personnel which can be immense, as observed during the SARS outbreak [36].

Furthermore, daily online video conferences of the senior professors and the assistant professor spokesman have been scheduled, so that arising issues can be discussed and solved. 
Then, the relevant information is circulated to the rest of the dental staff.

The first regulations enforced in the dental clinic were wearing a surgical face mask in all areas of the hospital, separate entrances for faculty members and patients, and a social distancing recommendation for the dental staff. Moreover, every employee of the department must monitor their health status daily. When an infection with SARS CoV-2 is suspected, the employee must stay home and inform the occupational medical service so that further actions can be taken such as immediate testing and isolation of contacts.

Home office options have been offered in order to rotate the personnel and keep them healthy while managing at the same time a variety of tasks such as preparing the online courses for the upcoming semester.

\section{Preparation of the facilities}

During the SARS outbreak in 2002, several reports of nosocomial infection clusters of healthcare providers and patients have been reported [37, 38]. Therefore, a joint on-site inspection of the dental clinic with members of the Department of Clinical Microbiology and Hospital Hygiene was held. During this inspection, existing clinical and hygiene protocols were adapted for the treatment of COVID-19 patients and further specified. Besides structuring the treatment procedures, access restrictions for patients and visitors, patients' pathways, and designated waiting areas as well as possible COVID-19 isolation rooms were inspected. Due to the possibility of aerosol contamination, the focus was to identify suitable isolation rooms with windows for fresh air circulation after the treatment. Therefore, two private isolation rooms were assigned for COVID-19 patients only, while a third private room had been selected as backup (Fig. 1). In these rooms, the air conditioning was switched off.

The treatment of inconspicuous dental emergency patients has been relocated in the undergraduate clinic facility. This clinic accommodates 40 dental units in one large room. Due to the possibility of viral transmission through air distribution [39], the incoming air was shut down and the exiting air was kept on, trying to create negative pressure throughout the undergraduate clinic. The treatment units are also near the windows to allow periodically exchange of fresh air after the treatments.

The waiting rooms have been cleared from flyers and magazines. In order to keep the recommended distance between patients, chairs were taped and labeled with social distancing signs (Fig. 2a). Furthermore, suspected or confirmed COVID19 patients are immediately separated from non-suspected patients. Ideally, they are transferred directly into the designated isolation rooms. If not available, the COVID-19 patient is seated in a waiting area which is separated from the regular patient waiting area (Fig. 2a and b).

Since the hospital restrooms may present a risk of SARSCoV-2 infection [40-42], the approach to provide suspected and confirmed COVID-19 only restrooms seemed reasonable. The COVID-19 restrooms in our hospital are located at the main entrance next to the checkpoint to ensure that no other employee or patient is using these allocated restrooms. COVID-19 patients are asked before putting on the protective gown at the checkpoint if they need to use the restroom.

\section{Patient information and screening}

After the instructions of the crisis task force to stop all elective dental treatments and focus on emergency cases only, efforts have been made to distribute this information to our patients. It is important that patients with a dental emergency are aware that treatments are possible and should not be afraid to visit the dental clinic. Patients can access our website and find the relevant COVID-19 information and how to get in contact with the department to seek treatment. Trained staff members then determine via tele screening the health status of the patient, clarify the dental emergency, and schedule appointments with sufficient time intervals to accommodate hygiene procedures.

Of utmost importance is the regulation of transportation of COVID-19-positive patients. In these cases, the local health authority ("Gesundheitsamt") must be contacted in advance to allow and coordinate the transport of the quarantined patient. Suspected but not confirmed cases should be advised to get in contact with their physician or the local health emergency service in order to get tested, ahead of the visit. If the dental emergency does not allow a delay, the patient is recommended to wear a facial mask and apply social distancing on the way to and from the dental clinic.

Since not all our patients get into contact with our department prior to their visit, further measures had to be taken. Our building accommodates the Department of Conservative Dentistry and Periodontology on the ground floor, the Department of Prosthetic Dentistry on the first floor, and the Department of Orthodontics on the second floor. The registrations of the three departments were merged in order to better control the patient influx. Additionally, all entrances were closed and only the main entrance of the building remained open for the public. Patient information posters about the availability of emergency treatment, entry restrictions, and appropriate hygiene recommendations can be found outside the main entrance and throughout the clinic. Each patient can only enter the clinic individually or with a legal guardian/ caretaker. At the entrance, a checkpoint has been stationed (Fig. 3) where dental staff members in personal protective equipment (PPE) screen the patients and grant them access 
Fig. 1 Example of isolation room

Fig. 2 a Waiting room. b COVID-19 waiting area
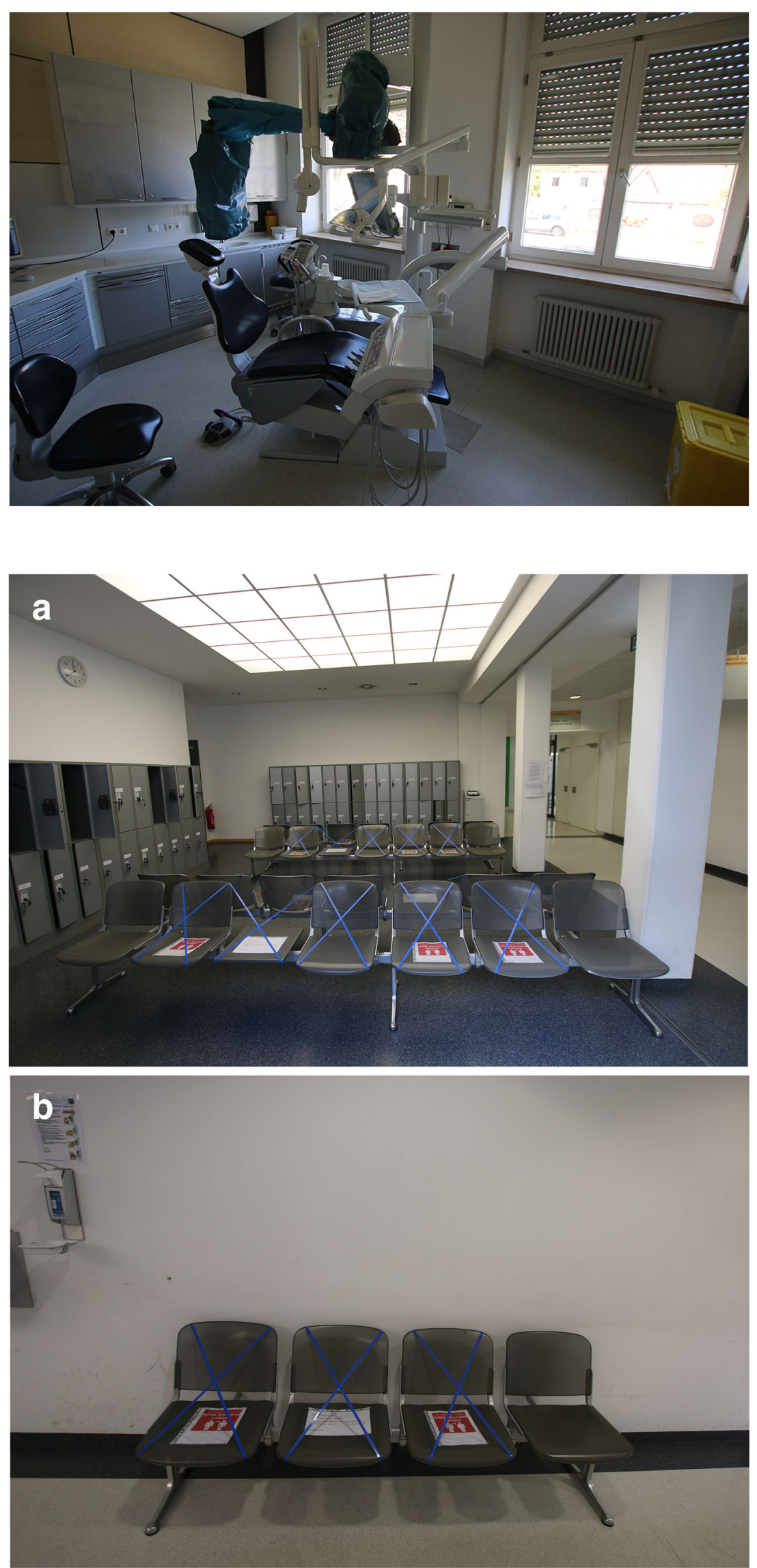
according to their risk profile while handing out an access permission paper. The screening consists of:

- Purpose of visit (dental emergency: yes/no)

- Measurement of the body temperature

- Questions regarding the state of health (fever, coughing, sore throat, diarrhea, vomiting)

- Questions regarding contact with a confirmed case of COVID-19

Due to the known susceptibility of infrared thermometer measurements to environmental temperature differences [43-45], it was decided to measure the body temperature with an ear thermometer.

If the patient has a temperature $>37.5{ }^{\circ} \mathrm{C}$ or answers a question in the affirmative, the patient is asked to perform a hygienic hand disinfection for $30 \mathrm{~s}$. Afterwards, a surgical mask is immediately handed out, while the correct placement over the nose and the mouth is supervised. Simultaneously, the dentist on duty is paged in order to assess if the patient is in need of emergency treatment or if the treatment can be postponed for at least 14 days after the first occurring respiratory or gastrointestinal symptoms. If the dentist on duty decides that treatment is necessary, the patient receives a protective gown (as well as the custodian) and is accompanied to the COVID-19 isolation room, while utmost care is given to prevent the patient from touching surfaces such as door handles and surfaces of the isolation room.

If the patient has no fever and an inconspicuous questionnaire, we provide a surgical mask after a 30-s hand disinfection. Afterwards, the patient is directed to the waiting room. Before completion of the checkpoint procedure, the doorman guarantees that no other patient is allowed in the clinic to ensure the adherence of distance regulations and prevention of crowding.

\section{Treatment of COVID-19 patients}

An emergency treatment contains treating the reason of the urgency while alleviating the discomfort of the patient [46]. The treatment itself has to be as effective as possible in order to prevent prolonged contact with an infected patient and simultaneously avoid or reduce procedures which generate aerosol and spatter. Similarly, it is crucial that the provided treatment ensures a follow-up appointment after the COVID19-related symptoms have subsided. A list of the emergency treatments can be found in Table 1 .

\section{Personal protective equipment (PPE)}

The following personal protective equipment is being used on COVID-19 confirmed and suspected patients (Fig.1):

- Long-sleeved virus-sealed waterproof gown

- Surgical cap/hood

- FFP3 respirators for confirmed COVID-19 cases/FFP2 respirators for suspected COVID-19 cases

- Safety goggles with side shields

- Face shield

- Double gloves

- Shoe cover

To secure proper and safe usage of PPE, the dental healthcare personnel was trained prior to their duty in the COVID-19 isolation rooms. Every participant was sensitized to the following aspects:
Fig. 3 Checkpoint during temperature measurement with an ear thermometer

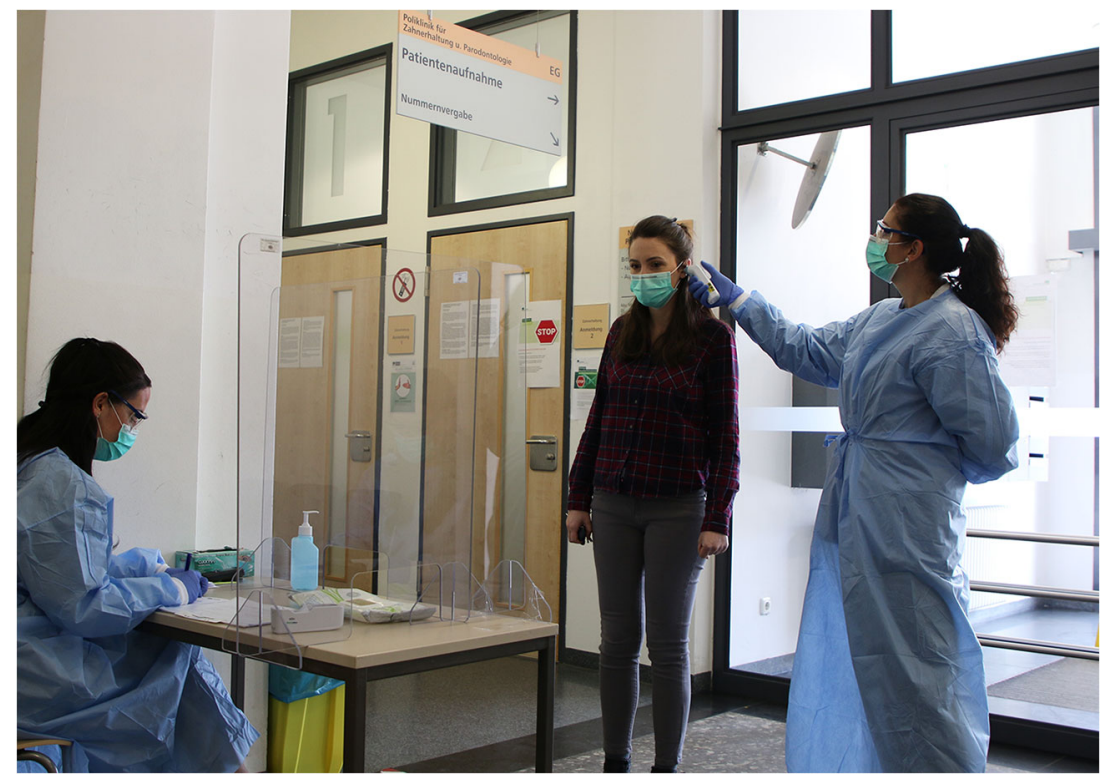


Table 1 Emergency treatment protocol of suspected or confirmed COVID-19 patients

\begin{tabular}{ll}
\hline Diagnosis $\quad$ Treatment & $\begin{array}{l}\text { Pharmacological } \\
\text { management }\end{array}$ \\
\hline
\end{tabular}

\begin{tabular}{|c|c|}
\hline & Restorative procedure \\
\hline $\begin{array}{l}\text { Pain due to filling } \\
\text { loss/deep cari- } \\
\text { ous lesion }\end{array}$ & $\begin{array}{l}\text { - Caries excavation } \\
\text { preferably with hand } \\
\text { instruments } \\
\text { - Provisional filling with } \\
\text { a glass ionomer } \\
\text { cement or composite } \\
\text { buildup material and } \\
\text { 1-step self-etch adhe- } \\
\text { sive } \\
\text { Endodontic procedure }\end{array}$ \\
\hline $\begin{array}{l}\text { Symptomatic } \\
\text { irreversible } \\
\text { pulpitis/apical } \\
\text { periodontitis }\end{array}$ & $\begin{array}{l}\text { - Access cavity } \\
\text { preparation strictly } \\
\text { under rubber dam } \\
\text { - Full pulpotomy } \\
\text { - Interim dressing } \\
\text { (Ledermix@) } \\
\text { - Temporary filling } \\
\text { material (Cavit@) }\end{array}$ \\
\hline $\begin{array}{l}\text { Symptomatic } \\
\text { apical } \\
\text { periodontitis } \\
\text { (previously } \\
\text { treated) }\end{array}$ & $\begin{array}{l}\text { - Restorable: } \\
\text { pharmacological } \\
\text { treatment } \\
\text { - Non-restorable: } \\
\text { extraction }\end{array}$ \\
\hline
\end{tabular}

- Nonopioid pain medication (acetaminophen $500 \mathrm{mg}$, if necessary) Nonopioid pain medication (acetaminophen $500 \mathrm{mg})+$ NSAID (ibuprofen $600 \mathrm{mg}$ ) if necessary
Table 1 (continued)

\begin{tabular}{|c|c|}
\hline Diagnosis & Treatment \\
\hline
\end{tabular}

\begin{tabular}{|c|c|c|}
\hline $\begin{array}{l}\text { Crown root } \\
\text { fracture with } \\
\text { pulp exposure }\end{array}$ & $\begin{array}{c}\text { probability of } \\
\text { treatment success } \\
\text { - Vital pulp therapy }\end{array}$ & $\begin{array}{l}\text { (acetaminophen } \\
500 \mathrm{mg} \text { ) if necessary }\end{array}$ \\
\hline $\begin{array}{l}\text { Horizontal root } \\
\text { fracture }\end{array}$ & $\begin{array}{l}\text { - Repositioning of the } \\
\text { coronal fragment and } \\
\text { splinting with } \\
\text { TTS/composite (ac- } \\
\text { cording to IADT } \\
\text { guidelines) }\end{array}$ & $\begin{array}{l}\text { - Nonopioid pain } \\
\text { medication } \\
\text { (acetaminophen } \\
500 \mathrm{mg} \text { ) if necessary }\end{array}$ \\
\hline Extrusion & $\begin{array}{l}\text { - Repositioning and } \\
\text { splinting with } \\
\text { TTS/composite (ac- } \\
\text { cording to IADT } \\
\text { guidelines) }\end{array}$ & $\begin{array}{l}\text { - Nonopioid pain } \\
\text { medication } \\
\text { (acetaminophen } \\
500 \mathrm{mg} \text { ) if necessary }\end{array}$ \\
\hline Lateral luxation & $\begin{array}{l}\text { - Repositioning and } \\
\text { splinting with } \\
\text { TTS/composite (ac- } \\
\text { cording to IADT } \\
\text { guidelines) }\end{array}$ & $\begin{array}{l}\text { - Nonopioid pain } \\
\text { medication } \\
\text { (acetaminophen } \\
500 \mathrm{mg} \text { ) if necessary }\end{array}$ \\
\hline Intrusion & $\begin{array}{l}\text { - Wait and observe } \\
\text { - Referral to OMF S * / } \\
\text { Orthodontic } \\
\text { Department for sec- } \\
\text { ond opinion }\end{array}$ & $\begin{array}{l}\text { - Nonopioid pain } \\
\text { medication } \\
\text { (acetaminophen } \\
500 \mathrm{mg} \text { ) if necessary }\end{array}$ \\
\hline Avulsion & $\begin{array}{l}\text { - Replantation and } \\
\text { splinting with } \\
\text { TTS/composite (ac- } \\
\text { cording to IADT } \\
\text { guidelines) }\end{array}$ & $\begin{array}{l}\text { - Nonopioid pain } \\
\text { medication } \\
\text { (acetaminophen } \\
500 \mathrm{mg} \text { ) } \\
-\geq 12 \text { years of age: } \\
\text { tetracycline } \\
\quad \text { (doxycyclin } 100 \mathrm{mg} \\
\times 7 \text { days } * \text { ) } \\
-\leq 12 \text { years of age: } \\
\text { aminopenicilline } \\
\text { (amoxicillin q.i.d. } \times \\
7 \text { days*) }\end{array}$ \\
\hline $\begin{array}{l}\text { Trauma involving } \\
\text { facial bone } \\
\text { structures }\end{array}$ & $\begin{array}{l}\text { - Referral to the OMFS } \\
\text { Department }\end{array}$ & $\begin{array}{l}\text { - Nonopioid pain } \\
\text { medication } \\
\text { (acetaminophen } \\
500 \mathrm{mg} \text { ) + NSAID } \\
\text { (ibuprofen } 600 \mathrm{mg} \text { ) if } \\
\text { necessary } \\
\text { - Aminopenicilline } \\
\text { (amoxicillin/- } \\
\text { clavulanic acid } \\
875 / 125 \mathrm{mg} \text { ) or } \\
\text { - Lincosamide } \\
\text { (clindamycin } 600 \mathrm{mg} \\
\times 5 \text { days) }\end{array}$ \\
\hline $\begin{array}{l}\text { Extraoral swelling } \\
\text { and cellulitis }\end{array}$ & $\begin{array}{l}\text { - Referral to OMFS } \\
\text { Department }\end{array}$ & $\begin{array}{l}\text { - Nonopioid pain } \\
\text { medication } \\
\text { (acetaminophen } \\
500 \mathrm{mg} \text { ) + NSAID } \\
\text { (ibuprofen } 600 \mathrm{mg} \text { ) if } \\
\text { necessary } \\
\text { - Aminopenicilline } \\
\text { (amoxicillin/- } \\
\text { clavulanic acid } \\
\text { 875/125 mg) or }\end{array}$ \\
\hline
\end{tabular}

(acetaminophen

Nonopioid pain

edication

$\begin{array}{ll}\text { splinting with } & \text { (acetaminophen } \\ \text { TTS/composite (ac- } & 500 \mathrm{mg} \text { ) if necessary }\end{array}$

splinting with

TS/composite (ac-

(acetaminophen

Nonopioid pain

medication

(acetaminophen

Nonopioid pain

medication

(acetaminophen

Nonopioid pain

medication

acetaminophen

$\mathrm{mg}$

tetracycline

(doxycyclin $100 \mathrm{mg}$

$\times 7$ days $*$ )

$\leq 12$ years of age:
- Nonopioid pain medication (acetaminophen $500 \mathrm{mg})+$ NSAID (ibuprofen $600 \mathrm{mg}$ ) if necessary
- Aminopenicilline (amoxicillin/- clavulanic acid $875 / 125 \mathrm{mg}$ ) or lincosamide (clindamycin $600 \mathrm{mg}$ $\times 5$ days) if necessary

Periodontal procedures

\begin{tabular}{|c|c|c|}
\hline $\begin{array}{l}\text { Acute periodontal } \\
\text { abscess }\end{array}$ & $\begin{array}{l}\text { - Subgingival } \\
\text { scaling/curettage with } \\
\text { hand instruments } \\
\text { - Incision and drainage } \\
\text { (if necessary) }\end{array}$ & $\begin{array}{l}\text { - Nonopioid pain } \\
\text { medication } \\
\text { (acetaminophen } \\
500 \mathrm{mg} \text { ) + NSAID } \\
\text { (ibuprofen } 600 \mathrm{mg} \text { ) if } \\
\text { necessary } \\
\text { - Aminopenicilline } \\
\text { (amoxicillin/- } \\
\text { clavulanic acid } \\
875 / 125 \mathrm{mg} \text { ) or } \\
\text { lincosamide } \\
\text { (clindamycin } 600 \mathrm{mg} \\
\times 5 \text { days) if necessary }\end{array}$ \\
\hline \multicolumn{3}{|c|}{ Trauma procedures } \\
\hline $\begin{array}{l}\text { Crown fracture } \\
\text { without pulp } \\
\text { exposure }\end{array}$ & $\begin{array}{l}\text { - Adhesive reattachment } \\
\text { of the fragment } \\
\text { - Adhesive cover with } \\
\text { flowable composite }\end{array}$ & $\begin{array}{l}\text { - Nonopioid pain } \\
\text { medication } \\
\text { (acetaminophen } \\
500 \mathrm{mg} \text { ) if necessary }\end{array}$ \\
\hline $\begin{array}{l}\text { Crown fracture } \\
\text { with pulp } \\
\text { exposure }\end{array}$ & $\begin{array}{l}\text { - Vital pulp therapy with } \\
\mathrm{Ca}(\mathrm{OH})_{2} \text { or tricalcium } \\
\text { silicate } \\
\text { - Adhesive cover with } \\
\text { flowable composite } \\
\text { - Removal of the crown } \\
\text { fragment to evaluate }\end{array}$ & $\begin{array}{l}\text { - Nonopioid pain } \\
\text { medication } \\
\text { (acetaminophen } \\
500 \mathrm{mg} \text { ) if necessary } \\
\text { - Nonopioid pain } \\
\text { medication }\end{array}$ \\
\hline
\end{tabular}


Table 1 (continued)

\begin{tabular}{lc}
\hline Diagnosis & $\begin{array}{l}\text { Pharmacological } \\
\text { management }\end{array}$ \\
\hline & - Lincosamide \\
(clindamycin $600 \mathrm{mg}$ \\
$\times 5$ days) if necessary \\
- Acetaminophen \\
$500 \mathrm{mg}(+$ ibuprofen \\
$600 \mathrm{mg})$
\end{tabular}

*OMFS oral and maxillofacial surgery department

- $\quad$ Long hair must be covered under the surgical cap, and men should remove facial hair for a correct seal of the respirator [47].

- Rigorous hand disinfection (30 s.) before putting on, during, and after the removal of the PPE.

- Seal testing of the respirator before entering the isolation area.

- High risk of contamination during removal ("doffing") of the PPE [48, 49]. The dentists and the dental nurses were advised to supervise each other during the procedure of putting on and taking off the personal protective equipment.

Although not explicitly mentioned by the Microbiology and Clinic Hygiene Department, we decided to recommend double gloving since it may reduce the risk of viral contamination, especially during the removal of the PPE [50, 51].

All asymptomatic patients are being treated in regular PPE (scrubs, surgical face masks, gloves, and safety goggles).

\section{Pre-treatment measures}

Our treatment concept consists of a dentist and a dental assistant within the isolation room, while outside, a standby dental nurse can be contacted to prepare and provide additional dental instruments or to escort the patient after completion of the treatment.

From the checkpoint, the standby dental nurse is informed that a suspected or confirmed COVID-19 patient has arrived. From there, the patient is accompanied to the isolation room while wearing a surgical face mask and a protective gown. In the isolation room, the patient is again encouraged to disinfect the hands for $30 \mathrm{~s}$. After taken seat in the dental chair, the health questionnaire as well as the first description of the dental emergency is completed, while the patient is still wearing the surgical face mask. Additionally, efforts have been made to digitize all paperwork like consent of treatment and information sheets while using signature pads for hygienic reasons.

Prior to the oral examination, the patient is encouraged to perform a mouth rinse with hydrogen peroxide $1 \%$ in two intervals ( $2 \mathrm{x}$ each $30 \mathrm{~s}$ ) since the virus seems sensitive to oxidation [7, 21]. Classic mouth rinses such as chlorhexidine have been shown to be less effective against SARS-CoV-2 [21]. When X-rays are required, extraoral radiographs (panoramic radiograph or $\mathrm{CBCT}$ ) should be favored to reduce gag or cough reflexes [31, 52].

All instruments and non-essential equipment have been removed from the isolation room drawers and benchtops. Therefore, all drawers are kept close so that the danger of contamination while opening them can be diminished. Consequently, we developed wrapped sterilized tray systems for different dental treatment procedures which can be retrieved on a trolley after contacting the standby nurse. The only exception is a clinical examination set which is placed on the tray of the dental unit before patient's arrival. The trays are equipped with the bare minimum of instruments which are needed to cover the different dental treatments (Table 2). Disposable materials such as composite carpules, adhesives, and rubber dam are delivered with the treatment tray by the standby nurse on request.

\section{Treatment measures}

All dental interventions are executed under four-handed dentistry principles as well as rubber dam isolation (preferably single tooth isolation) whenever possible since it has been confirmed that it can minimize the creation of aerosol and spatter $[53,54]$. The rubber dam is punched outside the isolation room and is provided with the rest of the instruments, as described above. Additionally, liquid rubber dam (OpalDam®, Ultradent) or putty material (OraSeal ${ }^{\mathrm{TM}}$, Ultradent) can be used to better seal the isolated tooth from the oral cavity. Then, the tooth and the rubber dam are disinfected with a cotton gauze soaked in alcohol (>70\%). If a high-speed handpiece has to be used, high and low suction devices are of utmost importance to reduce aerosol. Also, the 3-in-1 syringe should be used with caution [55]. Ultrasonic devices or air abrasion units are not advisable when treating suspected or confirmed COVID-19 cases due to the high generation of aerosol. Hand instruments should be the instrument of choice whenever possible (e.g., caries excavation with a hand excavator, a hand curette for periodontal pockets) [7].

\section{Posttreatment measures}

After the treatment, the patient removes his gown on his own and disposes it on the dental chair. A new surgical mask is handed out to the patient after repeating a 30-s hand disinfection. The patient is then being escorted by the standby nurse to the exit of the clinic in order to reduce contamination of surfaces. After the disinfection protocol of the instruments and the dental unit, the treatment team removes their PPE inside of the isolation room under mutual supervision with exception of 
Table 2 Tray sets for emergency dental treatment

\begin{tabular}{lllll}
\hline Basic instrumentarium & Rubber dam set & Endo set & Resto + trauma set & Perio set \\
\hline Dental mirrors (2x) & 3 clamps (e.g., HyFriedy \#2, \#9, \#14) & Access bur & Heidemann spatula (1x) & Gracey curette 5/6 \\
Periodontal probe (1x) & Rubber dam forceps & Long neck bur & Plugger (1x) & Gracey curette 13/14 \\
Dental probe (1x) & Rubber dam frame & C+-file ISO 10 (1x) & Diamond bur (cylinder) & Gracey curette 15/16 \\
Cotton forceps (2x) & & C+-file ISO 15 (1x) & Cotton pellets (5x) & Diamond bur (football) \\
Heidemann spatula & & & Excavating bur \\
Cotton rolls (3x) & & & Polisher (Brownie) \\
Cotton pellets (3x) & & & Articulating paper forceps \\
Suction & & Compules tips gun (1x) \\
3 in 1 syringe tips $(2 \mathrm{x})$ & & & \\
Dappen dish (1x) & & & \\
Swabs (1x) & & & \\
\hline
\end{tabular}

the respirator and position the discarded PPE in a designated bin for infectious waste. Before the dental team leaves the isolation room, the windows are opened for $30 \mathrm{~min}$ to ensure sufficient viral clearance. The respirators of the treatment team are then being removed outside of the isolation room into a second designated bin. The FFP2/FFP3 respirators are removed carefully and with closed eyes to avoid contamination of the conjunctiva and again under mutual supervision.

Next, the terminal disinfection of the isolation room (surfaces and floor) is being carried out by trained professional cleaning staff of the hospital in PPE (FFP2 respirators, gown, hood, and gloves), and the isolation room is closed for at least $1 \mathrm{~h}$ (closed windows) to guarantee an adequate exposure time of the surface disinfectants according to the influenza protocols.

A daily record of the dental teams and the treated patients is kept. This is a crucial step in case of an unsuspected patient or employee is diagnosed with COVID-19 to track and isolate contacts.

\section{Discussion}

We are confronted daily with new SARS-CoV-2 infections and growing numbers of fatalities. The significance of controlling the disease and flattening the curve of infections has become abundantly clear. Drastic measures had to be taken in order to prevent a collapse of the healthcare system.

It is apparent that the dental profession, as part of the healthcare system, will be confronted with the treatment of COVID-19 emergency patients. In this article, we describe in detail the measures taken in the Department of Conservative Dentistry and Periodontology in Munich. Nevertheless, these measures have certain limitations.
First, the majority of the measures are based on the experiences during the SARS outbreak in 2002. It is noteworthy that no dental health professional was infected during the SARS epidemic [56]. However, up to this date, the knowledge about the transmissibility of SARS-CoV-2 is limited and has to be interpreted with care when making recommendations for dental healthcare providers.

One of the biggest concerns regarding these policies is that we are not able to identify and isolate asymptomatic COVID19-positive patients. This leads to the treatment of potentially infected patients in regular protective equipment (scrubs, goggles, surgical masks) instead of higher protective gear. While it would be reasonable to treat every patient as potentially infected, it is unfortunately not possible due to the limited availability of PPE. On March 3, even before COVID-19 was officially designated a pandemic, the WHO warned about the shortage of PPE endangering healthcare workers all over the world [57]. Because of this shortage, it is apparent that a cautious use of PPE and priority usage in suspected or confirmed cases had to be recommended.

In the beginning of the pandemic, the Department of Restorative Dentistry and Periodontology received an initial stock of PPE through the crisis task force. However, the supply of FFP2 or FFP3 masks was strained throughout the University Hospital (KUM), and therefore, FFP2 and FFP3 masks could only be used on infected and suspected COVID19 patients.

This shortage leads to test the effectiveness of different decontamination methods of FFP respirators by the Department of Clinical Hygiene and Microbiology. Several attempts, for example, with ultraviolet germicidal irradiation, heat, and steam, have been reported in the literature, but the methods are not validated and consequently cannot be recommended yet [58]. 
At the same time, dental offices in the public sector were not recognized as essential for treating COVID-19 patients, and according to the distribution scheme of the Bavarian State Government, dental offices were therefore initially subordinated to receive PPE. On March 30, the Bavarian Dental Association (KZVB) appealed to the public emergency response authorities to recognize dentists as a high-risk profession in order to receive supplies of PPE. This intervention enabled the KZVB to support dental offices and hospitals treating COVID-19 patients by sending out an initial stock of PPE.

To this date, the resources of PPE have improved, but there are still limitations nationwide in parts because of the insufficient quality of the delivered FFP2 respirators. However, due to the success of the governmental restrictions such as the curfew ban, adhering to social distancing, and wearing masks in public buildings and transportations, the exponential growth of COVID-19 patients in Germany could be reduced, limiting also the number of cases treated in our dental hospital: From March 9 to April 9, 4 confirmed and 17 COVID-19suspected cases (5.5\% of all dental emergency patients) were treated. This circumstance led to the fact that our PPE supply was sufficient. Yet our experience in this respect is not transferable to the extremely difficult and even in parts unbearable circumstances in other countries, which were hit harder by the COVID-19 pandemic.

Therefore, one of the early lessons of the COVID pandemic is to set up a stockpile of PPE and materials such as an in ear thermometer, so that dentists are also adequately prepared for future health crises.

Another drawback is that up to this date, dental healthcare providers and patients are not tested, due to limited resources in laboratory tests, unless they show symptoms of a respiratory disease. Dentists and dental assistants are at high risk for infection with SARS-CoV-2 due to close proximity to the respiratory tract $[35,59]$. Testing of clinic staff as well as asymptomatic patients in need of dental emergency treatment should be enforced as soon as testing capacities are ramped up and new rapid tests are available, hopefully during the coming weeks. A first step in this direction has been taken at the LMU hospitals for patients in need of upper respiratory tract surgery. These patients are tested preoperatively so that PPE resources can be used rationally while ensuring the safety of the medical staff. However, PCR testing might not be possible for regular treatment of asymptomatic outpatients due to the high costs of repetitive testing.

In a unique situation like the COVID-19 pandemic, it is of utmost importance to be aware of possible fears of the dental staff. For example, when the checkpoint was established and staff members were appointed to manage the station, initial reluctance was observed because of fears of infection. Similar, when the directive to wear masks in all areas of the hospital was issued, part of the employees originally objected to this decision. Both instances could be resolved with intensive conversations and educational trainings to alleviate the raised concerns which stress the importance of transparent communication in times of crisis.

The measures described focus only on emergency treatments so that nosocomial infections can be avoided during the peak of the COVID-19 pandemic. However, these protocols only provide temporary solutions. To accommodate the dental needs of our patients, it is important to plan a transitioning phase and exit strategy in advance. As soon as the lack of resources regarding test capacity and personal protective equipment is eliminated, a relaxation of the measures or even a return to our regular procedure is possible and worth striving for.

In conclusion, the policies described, although being strict and time-consuming, have been set in place to help treat patients in a safe and effective manner. These measures can be modified to the specific needs of dental offices. However, the dental professionals should update their knowledge continuously through the dental and medical associations since new developments in the COVID-19 pandemic can alter measures to ensure a safe dental environment.

\section{Compliance with ethical standards}

Conflict of interest The authors declare that they have no conflict of interest.

Ethical approval This article does not contain any studies with human participants or animals performed by any of the authors.

Informed consent For this type of study, formal consent is not required.

\section{References}

1. Zhu N, Zhang D, Wang W, Li X, Yang B, Song J, Zhao X, Huang B, Shi W, Lu R (2020) A novel coronavirus from patients with pneumonia in China, 2019. N Engl J Med 382:727-733

2. Li Q, Guan X, Wu P, Wang X, Zhou L, Tong Y, Ren R, Leung KS, Lau EH, Wong JY (2020) Early transmission dynamics in Wuhan, China, of novel coronavirus-infected pneumonia. N Engl J Med 382:1199-1207

3. Coronaviridae Study Group of the International Committee on Taxonomy of Viruses (2020) The species severe acute respiratory syndrome-related coronavirus: classifying 2019-nCoV and naming it SARS-CoV-2. Nature Microbiology:1

4. World Health Organization (WHO) (2020) Novel coronavirus (2019-nCoV): situation report -11. https://www.who.int/ emergencies/diseases/novel-coronavirus-2019/situation-reports. Accessed 05.04.2020

5. Rothe C, Schunk M, Sothmann P, Bretzel G, Froeschl G, Wallrauch C, Zimmer T, Thiel V, Janke C, Guggemos W (2020) Transmission of 2019-nCoV infection from an asymptomatic contact in Germany. N Engl J Med 382:970-971

6. Bundesgesundheitsministerium. (2020) Chronik coronavirus. https://www.bundesgesundheitsministerium.de/coronavirus/ chronik-coronavirus.html. Accessed 05.04.2020 
7. Peng X, Xu X, Li Y, Cheng L, Zhou X, Ren B (2020) Transmission routes of 2019-nCoV and controls in dental practice. Int J Oral Sci 12(1):1-6

8. de Wit E, van Doremalen N, Falzarano D, Munster VJ (2016) SARS and MERS: recent insights into emerging coronaviruses. Nat Rev Microbiol 14(8):523-534

9. Fehr AR, Perlman S (2015) Coronaviruses: an overview of their replication and pathogenesis. In: Coronaviruses. Springer, pp 1-23

10. Zhou P, Yang X-L, Wang X-G, Hu B, Zhang L, Zhang W, Si H-R, Zhu Y, Li B, Huang C-L (2020) Discovery of a novel coronavirus associated with the recent pneumonia outbreak in humans and its potential bat origin. BioRxiv

11. Zou L, Ruan F, Huang M, Liang L, Huang H, Hong Z, Yu J, Kang M, Song Y, Xia J (2020) SARS-CoV-2 viral load in upper respiratory specimens of infected patients. N Engl J Med 382(12):11771179

12. He X, Lau EH, Wu P, Deng X, Wang J, Hao X, Lau YC, Wong JY, Guan Y, Tan X (2020) Temporal dynamics in viral shedding and transmissibility of COVID-19. medRxiv

13. Bai Y, Yao L, Wei T, Tian F, Jin D-Y, Chen L, Wang M (2020) Presumed asymptomatic carrier transmission of COVID-19. Jama

14. Tindale L, Coombe M, Stockdale JE, Garlock E, Lau WYV, Saraswat M, Lee Y-HB, Zhang L, Chen D, Wallinga J (2020) Transmission interval estimates suggest pre-symptomatic spread of COVID-19. medRxiv

15. Bai $Y$, Nie X, Wen C (2020) Epidemic prediction of 2019-nCoV in Hubei province and comparison with SARS in Guangdong province. Available at SSRN 3531427

16. Lu C-w, X-f L, Z-f J (2020) 2019-nCoV transmission through the ocular surface must not be ignored. Lancet 395(10224):e39

17. Wu Y-C, Chen C-S, Chan Y-J (2020) Overview of the 2019 novel coronavirus (2019-nCoV): the pathogen of severe specific contagious pneumonia (SSCP). J Chin Med Assoc

18. Robert Koch Institut (RKI) (2020) SARS-CoV-2 Steckbrief zur Coronavirus-Krankheit-2019 (COVID-19). https://www.rki.de/ DE/Content/InfAZ/N/Neuartiges Coronavirus/Steckbrief.html\# doc13776792bodyText1

19. World Health Organization (WHO) (2020) Modes of transmission of virus causing COVID-19: implications for IPC precaution recommendations: scientific brief, 27 march 2020. World Health Organization

20. van Doremalen N, Bushmaker T, Morris DH, Holbrook MG, Gamble A, Williamson BN, Tamin A, Harcourt JL, Thornburg NJ, Gerber SI (2020) Aerosol and surface stability of SARSCoV-2 as compared with SARS-CoV-1. N Engl J Med

21. Kampf G, Todt D, Pfaender S, Steinmann E (2020) Persistence of coronaviruses on inanimate surfaces and its inactivation with biocidal agents. J Hosp Infect

22. Otter J, Donskey C, Yezli S, Douthwaite S, Goldenberg S, Weber D (2016) Transmission of SARS and MERS coronaviruses and influenza virus in healthcare settings: the possible role of dry surface contamination. J Hosp Infect 92(3):235-250

23. Ong SWX, Tan YK, Chia PY, Lee TH, Ng OT, Wong MSY, Marimuthu K (2020) Air, surface environmental, and personal protective equipment contamination by severe acute respiratory syndrome coronavirus 2 (SARS-CoV-2) from a symptomatic patient. Jama

24. Guan W-J, Ni Z-Y, Hu Y, Liang W-h, Ou C-Q, He J-x, Liu L, Shan H, Lei C-L, Hui DS (2020) Clinical characteristics of 2019 novel coronavirus infection in China. MedRxiv

25. Zhang W, Du R-H, Li B, Zheng X-S, Yang X-L, Hu B, Wang Y-Y, Xiao G-F, Yan B, Shi Z-L (2020) Molecular and serological investigation of 2019-nCoV infected patients: implication of multiple shedding routes. Emerging Microbes Infect 9(1):386-389
26. Xiao F, Tang M, Zheng X, Li C, He J, Hong Z, Huang S, Zhang Z, Lin X, Fang Z (2020) Evidence for gastrointestinal infection of SARS-CoV-2. medRxiv

27. Linton NM, Kobayashi T, Yang Y, Hayashi K, Akhmetzhanov AR, S-m J, Yuan B, Kinoshita R, Nishiura H (2020) Incubation period and other epidemiological characteristics of 2019 novel coronavirus infections with right truncation: a statistical analysis of publicly available case data. J Clin Med 9(2):538

28. Robert Koch Institut (RKI) (2020) SARS-CoV-2 Steckbrief zur Coronavirus-Krankheit-2019 (COVID-19). https://www.rki.de/ DE/Content/InfAZ/N/Neuartiges_Coronavirus/Steckbrief.html. Accessed 11.04.2020

29. Wu Y, Guo C, Tang L, Hong Z, Zhou J, Dong X, Yin H, Xiao Q, Tang Y, Qu X (2020) Prolonged presence of SARS-CoV-2 viral RNA in faecal samples. Lancet Gastroenterol Hepatol 5(5):434 435

30. Lan L, Xu D, Ye G, Xia C, Wang S, Li Y, Xu H (2020) Positive RT-PCR test results in patients recovered from COVID-19. Jama

31. Meng L, Hua F, Bian Z (2020) Coronavirus disease 2019 (COVID19): emerging and future challenges for dental and oral medicine. Journal of Dental Research:0022034520914246

32. Bagheri SHR, Asghari AM, Farhadi M, Shamshiri AR, Kabir A, Kamrava SK, Jalessi M, Mohebbi A, Alizadeh R, Honarmand AA (2020) Coincidence of COVID-19 epidemic and olfactory dysfunction outbreak. medRxiv

33. Giacomelli A, Pezzati L, Conti F, Bernacchia D, Siano M, Oreni L, Rusconi S, Gervasoni C, Ridolfo AL, Rizzardini G (2020) Selfreported olfactory and taste disorders in SARS-CoV-2 patients: a cross-sectional study. Clin Infect Dis 70

34. Harrel SK, Molinari J (2004) Aerosols and splatter in dentistry: a brief review of the literature and infection control implications. J Am Dent Assoc 135(4):429-437

35. Center of Disease Control (CDC) (2020) Interim infection prevention and control guidance for dental settings during the COVID-19 response. https://www.cdc.gov/coronavirus/2019-ncov/hcp/dentalsettings.html. Accessed 12.04.2020

36. Chan AO, Huak CY (2004) Psychological impact of the 2003 severe acute respiratory syndrome outbreak on health care workers in a medium size regional general hospital in Singapore. Occup Med 54(3):190-196

37. Lee N, Hui D, Wu A, Chan P, Cameron P, Joynt GM, Ahuja A, Yung MY, Leung C, To K (2003) A major outbreak of severe acute respiratory syndrome in Hong Kong. N Engl J Med 348(20):19861994

38. Varia M, Wilson S, Sarwal S, McGeer A, Gournis E, Galanis E (2003) Investigation of a nosocomial outbreak of severe acute respiratory syndrome (SARS) in Toronto, Canada. Cmaj 169(4):285292

39. Li Y, Huang X, Yu I, Wong T, Qian H (2005) Role of air distribution in SARS transmission during the largest nosocomial outbreak in Hong Kong. Indoor Air 15(2):83-95

40. Liu Y, Ning Z, Chen Y, Guo M, Liu Y, Gali NK, Sun L, Duan Y, Cai J, Westerdahl D (2020) Aerodynamic characteristics and RNA concentration of SARS-CoV-2 aerosol in Wuhan hospitals during COVID-19 outbreak. bioRxiv

41. Ding Z, Qian H, Xu B, Huang Y, Miao T, Yen H-L, Xiao S, Cui L, Wu X, Shao W (2020) Toilets dominate environmental detection of SARS-CoV-2 virus in a hospital. medRxiv

42. Santarpia JL, Rivera DN, Herrera V, Morwitzer MJ, Creager H, Santarpia GW, Crown KK, Brett-Major D, Schnaubelt E, Broadhurst MJ (2020) Transmission potential of SARS-CoV-2 in viral shedding observed at the University of Nebraska Medical Center. medRxiv

43. Chen G, Xie J, Dai G, Zheng P, Hu X, Lu H, Xu L, Chen X, Chen X (2020) Validity of wrist and forehead temperature in temperature 
screening in the general population during the outbreak of 2019 novel coronavirus: a prospective real-world study. medRxiv

44. Erenberk U, Torun E, Ozkaya E, Uzuner S, Demir AD, Dundaroz R (2013) Skin temperature measurement using an infrared thermometer on patients who have been exposed to cold. Pediatr Int 55(6): $767-770$

45. Vesnovsky O, Li Y, Topoleski L, Zhu L Modeling of differences between body core and forehead temperatures measured by infrared thermometers. In: 2017 Design of Medical Devices Conference, 2017. American Society of Mechanical Engineers Digital Collection

46. American Dental Association (ADA) (2020) What constitutes a dental emergency. Available at: https://success.ada.org/ /media/ CPS/Files/Open\%20Files/ADA_COVID19_Dental_Emergency DDS.pdf? ga $=2.253879752 .110187285 .1584496315$ 1622146531.1565271894. Accessed 08.04.2020

47. Center of Disease Control (CDC) (2020) Facial hairstyles and filtering facepiece respirators. https://www.cdc.gov/niosh/npptl/ pdfs/FacialHairWmask11282017-508.pdf. Accessed 12.04.2020

48. Kwon JH, Burnham C-AD, Reske KA, Liang SY, Hink T, Wallace MA, Shupe A, Seiler S, Cass C, Fraser VJ (2017) Assessment of healthcare worker protocol deviations and self-contamination during personal protective equipment donning and doffing. Infection control \& hospital epidemiology 38 (9):1077-1083

49. Chughtai AA, Chen X, Macintyre CR (2018) Risk of selfcontamination during doffing of personal protective equipment. Am J Infect Control 46(12):1329-1334

50. Casanova LM, Rutala WA, Weber DJ, Sobsey MD (2012) Effect of single-versus double-gloving on virus transfer to health care workers' skin and clothing during removal of personal protective equipment. Am J Infect Control 40(4):369-374

51. Chen W-Q, Ling W-H, Lu C-Y, Hao Y-T, Lin Z-N, Ling L, Huang J, Li G, Yan G-M (2009) Which preventive measures might protect health care workers from SARS? BMC Public Health 9(1):81
52. Li R, Leung K, Sun F, Samaranayake L (2004) Severe acute respiratory syndrome (SARS) and the GDP. Part II: implications for GDPs. Br Dent J 197(3):130-134

53. Samaranayake L, Reid J, Evans D (1989) The efficacy of rubber dam isolation in reducing atmospheric bacterial contamination. ASDC J Dent Child 56(6):442-444

54. Ahmad I (2009) Rubber dam usage for endodontic treatment: a review. Int Endod J 42(11):963-972

55. American Dental Association (ADA) (2020 ) ADA interim guidance for minimizing risk of COVID-19 transmission. https:// success.ada.org/en/practice-management/patients/infectiousdiseases-2019-novel-coronavirus. Accessed 10.04.2020

56. Samaranayake LP, Peiris M (2004) Severe acute respiratory syndrome and dentistry: a retrospective view. J Am Dent Assoc 135(9): 1292-1302

57. World Health Organization (WHO) (2020) Shortage of personal protective equipment endangering health workers worldwide. https://www.who.int/news-room/detail/03-03-2020-shortage-ofpersonal-protective-equipment-endangering-health-workersworldwide. Accessed 10.04.2020

58. European Centre for Disease Prevention and Control (ECDC) (2020) Rapid risk assessment: coronavirus disease (COVID-19) pandemic: increased transmission in the EU/EEA and the UK seventh update. Accessed 12.04.2020

59. The Occupational Safety and Health Administration (OSHA) (2020) Administration's guidance on preparing workplaces for COVID-19. https://www.osha.gov/Publications/OSHA3990.pdf. Accessed 12.04.2020

Publisher's note Springer Nature remains neutral with regard to jurisdictional claims in published maps and institutional affiliations. 